\title{
RANKING OF LIGNITE DEPOSITS IN POLAND ESTABLISHED ON THE BASIS OF THE ANALYTIC HIERARCHY PROCESS
}

\author{
Dr. Eng. Anna Ostręga* \\ Mining and Geoengineering Faculty \\ AGH University of Science and Technology \\ Cracow, Poland \\ E-mail: ostrega@agh.edu.pl \\ Professor Ryszard Uberman \\ Mining and Geoengineering Faculty \\ AGH University of Science and Technology \\ Cracow, Poland \\ E-mail: $\underline{\text { ubeman@agh.edu.pl }}$
}

\begin{abstract}
The design of the mineral deposit development and also protection of particularly valuable deposits against the development of their surfaces for investments other than mining require an estimation of the value and usefulness of the documented deposits for the economy as well as their classification in this context. Rankings (order) of mineral deposits were established on the basis of expert evaluation using the point method, which is characterized by a large dose of subjectivity. As such, it was necessary to establish an objective hierarchy to support such an important decision as the development (or non-development) of lignite deposits.

The Analytic Hierarchy Process, which enables the estimation of mineral deposits in a more complex manner than the point method, was proposed for establishing a ranking of lignite deposits. For this purpose, a multi-criteria decision model was build. In the estimation of deposits, all factors that can have an influence on the attractiveness of their development were taken into account. An estimation of lignite deposits which were selected on the basis of previous rankings was carried out by using a questionnaire prepared on the basis of the decision model, taking into account assessments from previous rankings. The estimation obtained in this manner underwent mathematical verification with the use of Expert Choice software, the effect of which is the hierarchy of the factors as well as the ranking of lignite deposits.
\end{abstract}

Keywords: lignite deposits, valorisation, ranking, analytic hierarchy process

\section{Introduction}

Poland is rich in natural raw materials, including lignite deposits. At the present time, there are more than 150 documented lignite deposits. They are characterized by a differentiated range of attractiveness regarding the possibility of their development, which include first and foremost:

- the amount of resources,

- conflict with the legally established form of nature protection,

- conflict with existing development of real estate with mineral deposits,

- conflict with plans for the designation of real estate with mineral deposits for investments other than mining,

* Corresponding author 
- social acceptance of mining investments.

Not all of the documented lignite deposits are qualified to be protected for the purposes of mining investments, therefore it is necessary to establish their ranking, which will show the order of their development. Establishment of a ranking of lignite deposits according to fixed estimation criteria is needed for programming the development of a given branch of mining. Significant development of extraction of lignite deposits with reference to existing mineral resources is planned as part of Poland's program concerning the energy policy (Energy policy guidelines, 2005). Before making a decision on the development of mineral deposits, there is a need to choose deposits, which are available and which are characterised by the best technical and economical affectivity of extraction. The problem of mineral deposits development is especially visible when the amount of recognized mineral resources is numerous.

The valorisation of mineral deposits is also necessary in order to specify the requirements concerning their protection. Not all mineral deposits should take priority over other elements of the environment in terms of their protection. Therefore estimation must be carried out of the value of particular mineral deposits in order to establish their meaning for the economy, taking environmental conflicts into account in the case of mineral deposits' development (Nieć 2004).

An important factor influencing the mineral deposits' attractiveness is the social acceptance of such investments. The legal regulations in force make it possible for the community to express its comments and remarks concerning the planned investments. Since investments concerning mine building are connected with significant environmental conversion, they usually do not receive social acceptance. Even though the local community's comments may be rejected after the decision is made, their objections may influence the local government's decision.

The meaning of lignite deposits for the Polish economy and the rich resources of this mineral at the same time are reflected in studies concerning mineral deposits' valorisation and establishment of their ranking which have been prepared by different institutions. The aim of establishing the ranking is the selection of the most attractive mineral deposits for development, and then their protection against investments other than mining. Studies, the aim of which was the valorisation and ranking of mineral deposits, may be found in the subject literature. In those studies, the valorisation of the mineral deposits was usually limited to their estimation using geological-mining, environmental and spatial factors whereas the sum of the points established by the experts in the point procedure acted as a tool for establishing the position of given deposits. Hence, the listed limitations did not reflect the actual situation.

As a result, the search for a different method, which would allow for a complex valorisation of mineral deposits and the establishment their ranking, was necessary. An attempt was made to apply the AHP method, which considers both the numerical and non-numerical factors that characterise mineral deposits. The usefulness of this method was verified on the basis of lignite deposits' valorisation.

\section{Review and description of the selected methods of mineral deposits' valorisation}

One of the first Polish studies on open cast mining concerning the valorisation of mineral deposits was the expert opinion of the Polish Academy of Law - Poznań Department entitled "Natural, social and economical effects of the Posnanian lignite deposits extraction" (1980). The aim of the opinion was to define the effects which can be caused by extraction of the Mosina-Gostyn lignite deposits in the Wielkopolska region. The evaluation was focused on the effects (threats) on the environment. In the evaluation method the following factors were taken into account: water condition disturbances (ground and underground water), changes in the farming industry (including not only losses in production, but also social effects), costs of liquidation of industrial infrastructure, housing and others areas, costs of liquidation and renovation of technical and social infrastructure as well as other effects which are difficult 
to estimate in financial terms. The results of the opinion included the evaluation of losses in the amount of PLN 630 billion (price from 1976), which would be caused after development of the Mosina-Gostyń lignite deposits located in the Wielkopolska region and the conclusion that the losses are much higher then the benefits which can be gained from the deposits' extraction.

The next study in the field of the valorisation of mineral deposits is the expert opinion prepared by the Mineral and Energy Economy Research Institute at the Polish Academy of Sciences (KGSM PAN) entitled: "Complex exploitation and development of lignite extraction areas in Poland" (1982). The aim of the study was to establish the order of the development of lignite deposits. A hierarchical method based on totalling ranks (points) was used for this purpose. A dozen of prospective lignite deposits evaluated according to different groups of factors (criteria): geological, mining, ecological, social and spatial (land development) were the subject of the analysis. Classification of the prospective lignite deposits in terms of their development was the result of the research (table 1).

Table 1. Classification of prospective lignite deposits prepared on the basis of the point method (sum of rank) according to the KGSM PAN evaluation

\begin{tabular}{|c|c|c|c|c|c|c|c|}
\hline & \multirow[b]{2}{*}{ Deposit } & \multicolumn{6}{|l|}{ Criteria } \\
\hline & & $\begin{array}{l}\text { Geological- } \\
\text { mining }\end{array}$ & Mining & Environmental & Social & Spatial & \begin{tabular}{|l} 
Points total \\
(rank)
\end{tabular} \\
\hline 1 & Trzcianka & 4 & 4 & 2 & 4 & 4 & 18 \\
\hline 2 & Mosty & 4 & 4 & 4 & 4 & 2 & 18 \\
\hline 3 & Gubin & 2 & 4 & 4 & 4 & 2 & 16 \\
\hline 4 & Babina & 2 & 4 & 2 & 4 & 4 & 16 \\
\hline 5 & Złoczew & 0 & 2 & 4 & 4 & 4 & 14 \\
\hline 6 & Cybinka & 2 & 2 & 2 & 2 & 4 & 12 \\
\hline 7 & Legnica East & 4 & 2 & 2 & 0 & 4 & 12 \\
\hline 8 & Legnica North & 0 & 2 & 2 & 0 & 4 & 8 \\
\hline 9 & Ścinawa & 0 & 0 & 4 & 0 & 4 & 8 \\
\hline 10 & Legnica West & 2 & 0 & 2 & 0 & 2 & 6 \\
\hline 11 & Rogoźno & 0 & 0 & 0 & 2 & 0 & 2 \\
\hline 12 & Czempin* & 0 & 0 & 0 & 0 & 0 & 0 \\
\hline 13 & Krzywin* & 0 & 0 & 0 & 0 & 0 & 0 \\
\hline 14 & Gostyń* & 0 & 0 & 0 & 0 & 0 & 0 \\
\hline
\end{tabular}

*The Czempin, Krzywin and Gostyń deposits were evaluated negatively in the study due to the high value of the area of their location

The deposits which received the highest score were deemed as the most useful for development. A hierarchical method based on totalling points was the first at that time attempt at complex analysis of the effects, which could be caused after the development of the analysed deposits.

The study entitled "The eco-economic method of lignite deposits' valorisation" was the next work developing the issue of the evaluation and valorisation of lignite deposits (Piwocki, Kasiński, 1993). The same authors also developed the first Polish "Eco-economic map of lignite deposits' valorisation" in a scale 1:750 000 issued by the Polish Geological Institute (1994). This study is the largest analysis and valorisation of Polish lignite deposits. In total 158 lignite deposits were analysed divided into three groups: main deposits, satellite deposits and local deposits. Lignite deposits were characterised by different factors, which were divided into two groups:

- Economic (deposit resources, qualitative parameters of the lignite, geological parameters of the deposit, presence of accompanying minerals and hydro-geological conditions),

- Ecological (forest and agriculture economy, structures and areas protected by low spatial development plus surface and underground water). 
The economic and ecological values were estimated separately using the point method. A synthetic coefficient, which is a quotient of the economic and ecological point values, was used for the evaluation of the total value of lignite deposits. This was the basis for making a classification of the deposit values by assigning each of the evaluated deposits to one of the classes on the logarithm scale (table 2).

Table 2. Logarithm scale of the deposits value

\begin{tabular}{|l|l|}
\hline Deposit value & Value coefficient \\
\hline very high & $2.02-2.75$ \\
\hline high & $1.48-2.02$ \\
\hline medium & $1.09-1.48$ \\
\hline mediocre & $0.80-1.09$ \\
\hline low & $0.60-0.80$ \\
\hline
\end{tabular}

(source: Piwocki, Kasiński, 1994)

A map prepared on the basis of the results of the deposits' values constitutes a graphical representation of the study.

After a long break two subsequent studies were carried out concerning the valorisation of lignite deposits. The first one entitled "The method of programming of deposit development in the multi-open cast lignite mine" was related to the manner of establishing the development order of lignite deposits within the framework of an open cast mine (Kasztelewicz, 2005). The applied method refers to the valorisation of a small number of lignite deposits located in the mining-energy region, and as such it does not include all lignite deposits in Poland. Yet, due to the tools and methodology used in the method it could be useful for the preparation of a nationwide technical-economic valorisation of lignite deposits. The application of economical aspects in a wider scope was the novelty of this method in comparison to previous ways of mineral deposits' ranking.

The next study entitled "Valorisation and ranking-list of lignite deposits in Poland" constituted important progress in the field of lignite deposits' valorisation (Kasiński, Mazurek, Piwocki, 2006). Some valuable features of the method presented in this study include:

- Development of the point method through the specification and introduction of new factors (criteria),

- Application of a so called utopian point for the deposits' classification,

- Implementation of economic factors in a simplified form, but commensurate with deposit recognition and details of design solutions.

As opposed to the commonly applied chronology of action for the selection of the best solution, the first selection of the mineral resources was made on the basis of an initial evaluation of the profitability of their development taking into account the deposit value parameter. The characteristics of quantitative and qualitative features of the mineral deposits, as well as geological-mining and geographical-economic criteria adopted for the evaluation were the basis for the economic valorisation of the lignite deposits. In the next stages, the valorisation of the lignite deposits was made using the point method or the utopian point method. The degree of potential conflict between mineral extraction and the environment was also established as part of the valorisation. Social valorisation was the last stage of the lignite deposit valorisation. At the first stage of the economic analysis 41 lignite deposits were selected as potentially profitable for extraction, out of which 12 were not accepted because of environmental conflict, and five did not obtain social acceptance. As a result of the above, 24 deposits met all criteria at the same time (table 3). 
Table 3. Ranking of economic lignite deposits in Poland

\begin{tabular}{|c|c|c|c|}
\hline & Name of deposit & Billion PLN & $\begin{array}{l}\text { Intrinsically economic resources (billion } \\
\text { tons) }\end{array}$ \\
\hline 1 & Gubin & 31701 & 1143.3 \\
\hline 2 & Rogóźno & 16997 & 772.8 \\
\hline 3 & Gubin-Brody & 12431 & 76.3 \\
\hline 4 & Złoczew & 7357 & 485.6 \\
\hline 5 & Trzcianka & 2411 & 610.2 \\
\hline 6 & Piaski & 2078 & 103.6 \\
\hline 7 & Głowaczów & 1298 & 76.3 \\
\hline 8 & Czerwona Woda-Parzyce* & 1269 & 42.4 \\
\hline 9 & Łęki Szlacheckie SE* & 1152 & 49.8 \\
\hline 10 & Mosty & 1134 & 381.1 \\
\hline 11 & Wąbrzeźno* & 1025 & 34.6 \\
\hline 12 & Tomisławice & 958 & 54,9 \\
\hline 13 & Piotrków Kujawski** & 709 & 22,5 \\
\hline 14 & Węglewice & 647 & 50.4 \\
\hline 15 & Parowa-Ruszów-Węgliniec & 487 & 36.1 \\
\hline 16 & Uniejów* & 379 & 40.0 \\
\hline 17 & Toporzysko-Czamowo & 323 & 29.3 \\
\hline 18 & Torzym & 314 & 1005.5 \\
\hline 19 & Bieganów & 312 & 38.9 \\
\hline 20 & Mąkoszyn-Grochowiska & 272 & 48.8 \\
\hline 21 & Morzyczyn & 145 & 26.1 \\
\hline 22 & Radziejów & 121 & 52.4 \\
\hline 23 & Przewóz-Iłowa-Węgliniec & 70 & 22.9 \\
\hline 24 & Głowno & 17 & 37.4 \\
\hline
\end{tabular}

* recognized deposits ** deposits proposed for removal from the Balance of Raw Material Resources in Poland (source: Kasiński, Mazurek, Piwocki, 2006)

Upon analysis of the 24 most attractive lignite deposits, the following conclusions can be reached:

- the potentially large number of documented and recognized lignite deposits is significantly limited in terms of their development to 41 deposits that meet the economic criterion;

- only a few (Gubin, Rogóżno, Złoczew, Trzcianka, Mosty, Torzym) of the 24 so called industrial lignite deposits from table 3 that meet at the same time the economic, environmental and social acceptance criteria fixed in the study are of significance for the power industry;

- in spite of significant resources and their economical profitability Legnica East and Legnica West as well as the Wielkopolskie region deposits were not included on the ranking list of 24 deposits due to their conflict with the environment;

- in the case of large lignite deposits, those in the Wielkopolskie region, Legnica East and to a lesser extent in Legnica West did not obtain social acceptance for development.

A characteristic feature of the methods of valorisation and ranking of mineral deposits which were applied in the presented studies is the focus on the limited group of criteria, first of all geological, spatial and environmental as well as the choice of relatively simple tools for the deposits' ranking in the form of a point scale. In the published methods of mineral deposits' valorisation, so far the economic factor has been taken into account but only as auxiliary. 
Besides the studies listed above that address the problem of mineral deposits' valorisation in a comprehensive manner (method, procedures, classification, ranking) some studies also exist that partly deal with this problem or they are concerned with deposits other than lignite deposits. Among the studies dealing with ranking, although not that of deposits but that of post-mining structures, we should list the study by E. Pietrzyk-Sokulska entitled: "Criteria and modes of adaptation of areas after industrial rock extraction. A study of selected areas of Poland" (2005). In this study, the Wrocław taxonomy method was used in order to rank the analysed objects taking into account their usefulness and the efficiency of their regeneration.

The $\mathrm{PhD}$ thesis of A. Ostrega "The ways of the revitalization the voids and sites after carbonate raw materials extraction on the basis of the Krzemionki Podgórskie region in Cracow" (2004) is another example in which an analytic hierarchy process (AHP) was applied in order to choose the best concept of post mining region revitalisation. An outstanding feature of the AHP method is the possibility of using numerical (parameters, indicators) and non- numerical factors (descriptions).

The last of the listed studies, which showed the usefulness of the AHP method for the selection of the best concept of revitalisation became an inspiration for the application of this method for such an important problem as protection of mineral deposits.

\section{Establishment of the ranking of lignite deposits using the AHP method}

\subsection{Initial assumptions}

The subject of the analysis is a group of lignite deposits chosen from the studies listed below:

- "Complex exploitation and development of lignite extraction areas in Poland" (KGSM PAN 1982),

- “Eco-economic map of lignite deposits' valorisation" (PGI 1994),

- "Valorisation and ranking-list of lignite deposits in Poland" (PGI 2006).

Different amounts of deposits were analyzed in the mentioned studies. The largest group of deposits was analyzed in the study of Piwocki and Kasiński (1994), consisting of 158 deposits, including 47 so called main deposits, 56 satellite deposits and 55 local deposits. In the study of Kasiński, Mazurek, Piwocki (2006) 41 deposits were classified for further analysis on the basis of an initial economic evaluation. In the KGSM PAN Expert Opinion (1982) attention was focused on 14 main deposits which could constitute a fuel base for the electrical power industry.

Different kinds of factors that influence the attractiveness of lignite deposits were analysed in the studies listed above:

- geological-mining

- environmental,

- spatial development of real estate

- social

- economic (although in a simplified range and limited to one indicator).

However, none of the studies included a full set of the factors mentioned above. Preliminary elimination of lignite deposits as regards legal limitations (type of environmental protection) of the possibility for their development was not conducted.

The following was assumed in order to valorise and rank lignite deposits using the AHP method:

- the subject of the analysis is a group of lignite deposits recognized as the most attractive for development and selected from the studies of KGSM PAN (1982) and PIG (1994, 2006) presented in table 4; 
- only deposits with resources enabling construction of a power plant with power over $500 \mathrm{MW}$ were analysed; therefore they are so called main deposits, and the Złoczew deposit in terms of satellite deposits;

- a potential base of resources which were subject to analysis was checked in terms of legal limitations which could made the development impossible (due to environmental protection);

- measurable and non-measurable factors which determined lignite deposits' evaluation were taken into consideration whereby expert evaluations were taken from the previous listed studies.

On the basis of the described assumptions for establishment of a ranking of lignite deposits using the AHP method lignite deposits were chosen from the existing rankings (table 4).

Table 4. List of lignite deposit rankings

\begin{tabular}{|c|c|c|c|}
\hline & KGSM, 1982 & PGI, 1994 & PGI, 2006 \\
\hline & $\begin{array}{l}\text { Factors: } \\
\text { Geological } \\
\text { Mining } \\
\text { Environmental } \\
\text { Social } \\
\text { Spatial }\end{array}$ & $\begin{array}{l}\text { Factors: } \\
\text { Economic } \\
\text { Environmental }\end{array}$ & $\begin{array}{l}\text { Factors: } \\
\text { Geological-industrial } \\
\text { Economic } \\
\text { Environmental } \\
\text { Social }\end{array}$ \\
\hline 1 & Trzcianka & Mosty & Gubin \\
\hline 2 & Mosty & Legnica East & Rogoźno \\
\hline 3 & Gubin & Legnica West & Złoczew \\
\hline 4 & Złoczew & Gubin & Trzcianka \\
\hline 5 & Legnica East & Rogoźno & Mosty \\
\hline 6 & Legnica West & Trzcianka & Torzym \\
\hline 7 & Rogoźno & Złoczew & Legnica West \\
\hline 8 & Torzym & Torzym & Legnica East \\
\hline
\end{tabular}

Listed intrinsically economic lignite deposits are shown in table 5.

Table 5. Intrinsically economic lignite deposits

\begin{tabular}{|l|l|c|}
\hline & Name of deposit & $\begin{array}{l}\text { Intrinsically economic } \\
\text { (billion Mg) }\end{array}$ \\
\hline 1 & Gubin & 1143.3 \\
\hline 2 & Rogóźno & 772.8 \\
\hline 3 & Złoczew & 485.6 \\
\hline 4 & Trzcianka & 610.2 \\
\hline 5 & Mosty & 381.1 \\
\hline 6 & Torzym & 1005.5 \\
\hline 7 & Legnica West & 863.6 \\
\hline 8 & Legnica East & 839.3 \\
\hline
\end{tabular}

The influence of mineral extraction on the environment has been taken into consideration in the studies carried out to date without the exclusion of the deposits the exploitation of which would be limited or impossible in the light of legal regulations. It emerges from the analysis of the Natura 2000 areas and the location of lignite deposits that areas part of the Natura 2000 network will determine the possibility of the development of such deposits as Cybinka, Mosty, Torzym, Rzepin and also Legnica East and Legnica West once the shadow list is accepted. The current legal regulations on environmental protection do not exclude from analysis any of the documented or recognised main lignite deposits (unless they are located in national park or natural reserve areas). 


\subsection{Ranking of lignite deposits in Poland established on the basis of the AHP}

According to the assumptions defined in chapter 3.1 an attempt was made to apply the AHP method for establishment of a ranking of lignite deposits. The following deposits chosen from existing rankings by KGSM PAN (1982) and PGI (1994, 2006) were taken into consideration: Gubin, Rogoźno, Złoczew, Trzcianka, Mosty, Torzym, Legnica West and Legnica East. A hierarchical decision model was created consisting of three levels: the main goal - ranking of lignite deposits, the key criteria - factors characterising lignite deposits and the alternatives - lignite deposits. The model is presented in figure 1.

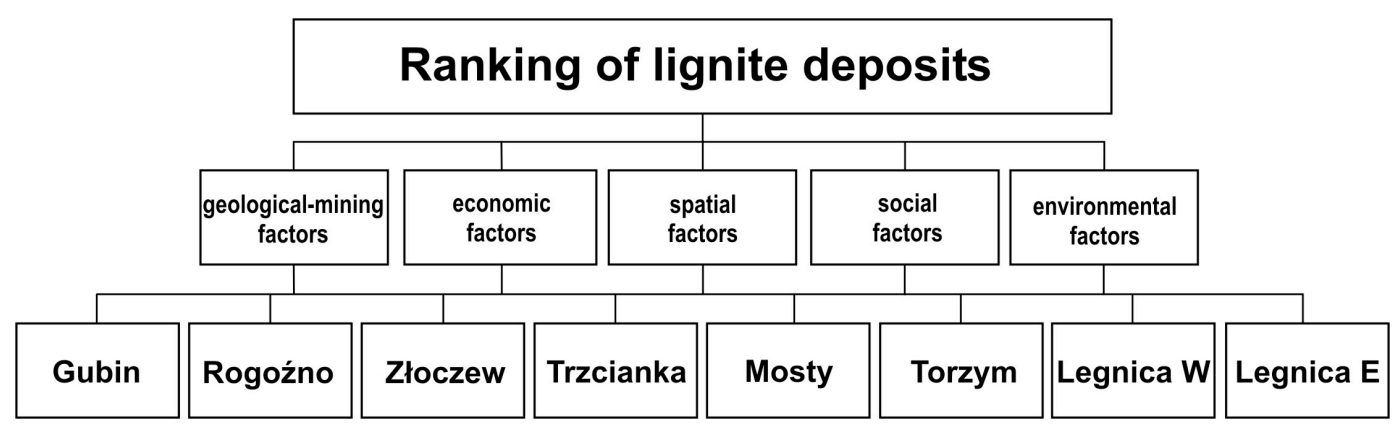

Figure 1. Hierarchical decision model for establishing the ranking of lignite deposits from the point of view of the attractiveness of their development

On the basis of the hierarchical decision model, a two-part expert questionnaire was prepared for assessment of the relative importance of elements located on particular levels of the hierarchy. The first part contained a combination of criteria - factors, which have influence on the attractiveness of the development of the lignite deposits. The criteria were compared with one other taking into account the goal - the establishment of a ranking of lignite deposits. The second part of the questionnaire is a comparison of alternatives in the form of lignite deposits in which lignite deposits were compared with one another in terms of their characterising factors. A verbal scale was used for the evaluation, for which points were then assigned.

In practice, a group of experts -several specialists from the field - should make an assessment of the elements included in the questionnaire. Yet for the purposes of the present paper, only factors were estimated by experts while an evaluation of lignite deposits was made on the basis of their position in existing rankings. The results obtained via this method were subject to mathematical verification using the Expert Choice program, whose effect is a hierarchy of factors as well as a ranking of lignite deposits expressed with the use of priority vectors. The weight of the factors calculated on the basis of the comparison matrix and which reflect their significance for the main goal create the priority vector, which consists of:

$W_{\text {factors }}=\left(0,387_{\text {geological-mining }} ; 0,356_{\text {economic }} ; 0,131_{\text {environmental }} ; 0,090_{\text {spatial }} ; 0,035_{\text {social }}\right)$

The priority vector is also shown in picture 2 . 


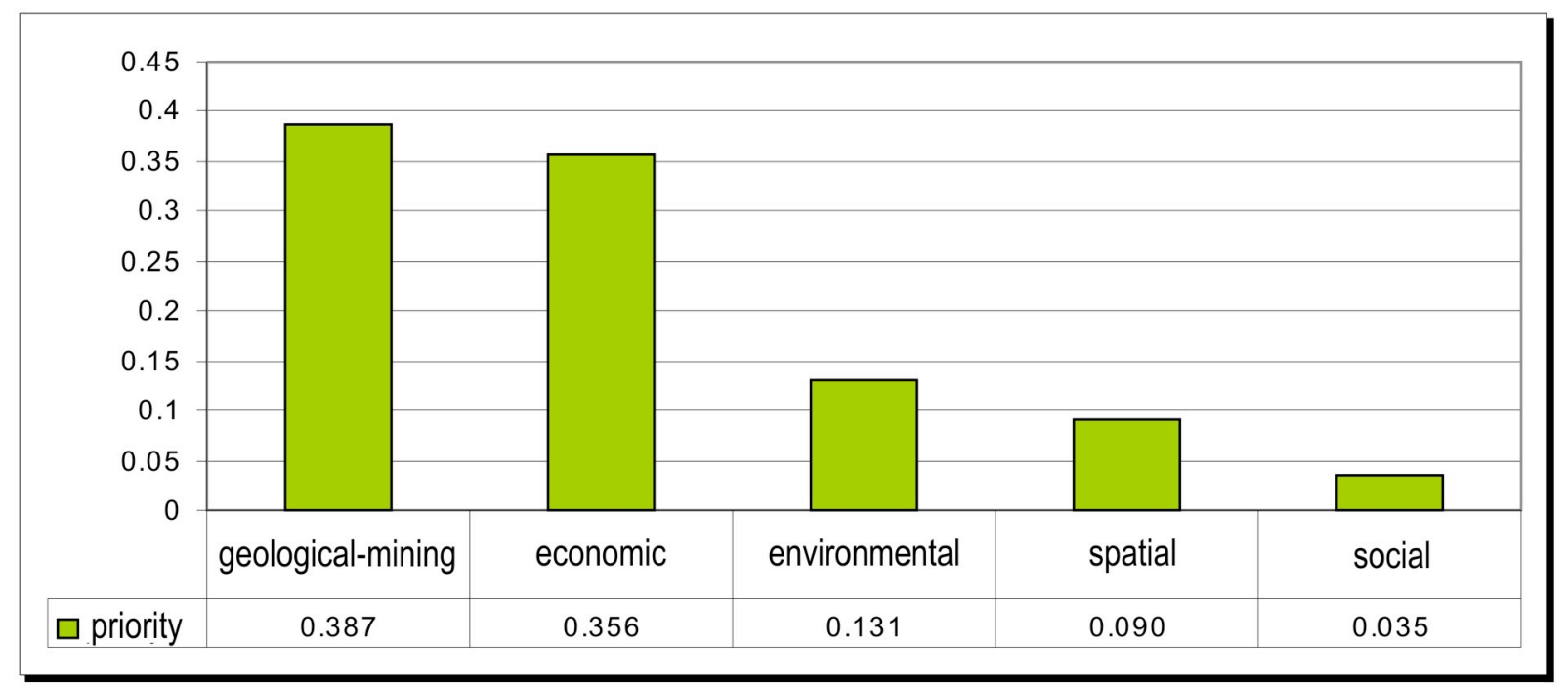

Figure 2. Global vector for the main criteria - factors characterising the lignite deposits

The priority vector components indicate that the most important factors for the experts regarding the attractiveness of lignite deposits' development are: geological-mining, economic and then environmental factors. Spatial and social factors are less important for the goal. The factor hierarchy is reflected in the form of a global priority vector of alternatives - lignite deposits. The global priority vector is presented in model 2 and figure 3 .

$W_{\text {deposits }}=\left(0,222_{L W} ; 0,212_{G} ; 0,130_{L E} ; 0,128_{Z} ; 0,127_{R} ; 0 ; 082_{T} ; 0,057_{M} ; 0,044_{\text {Torz }}\right)$

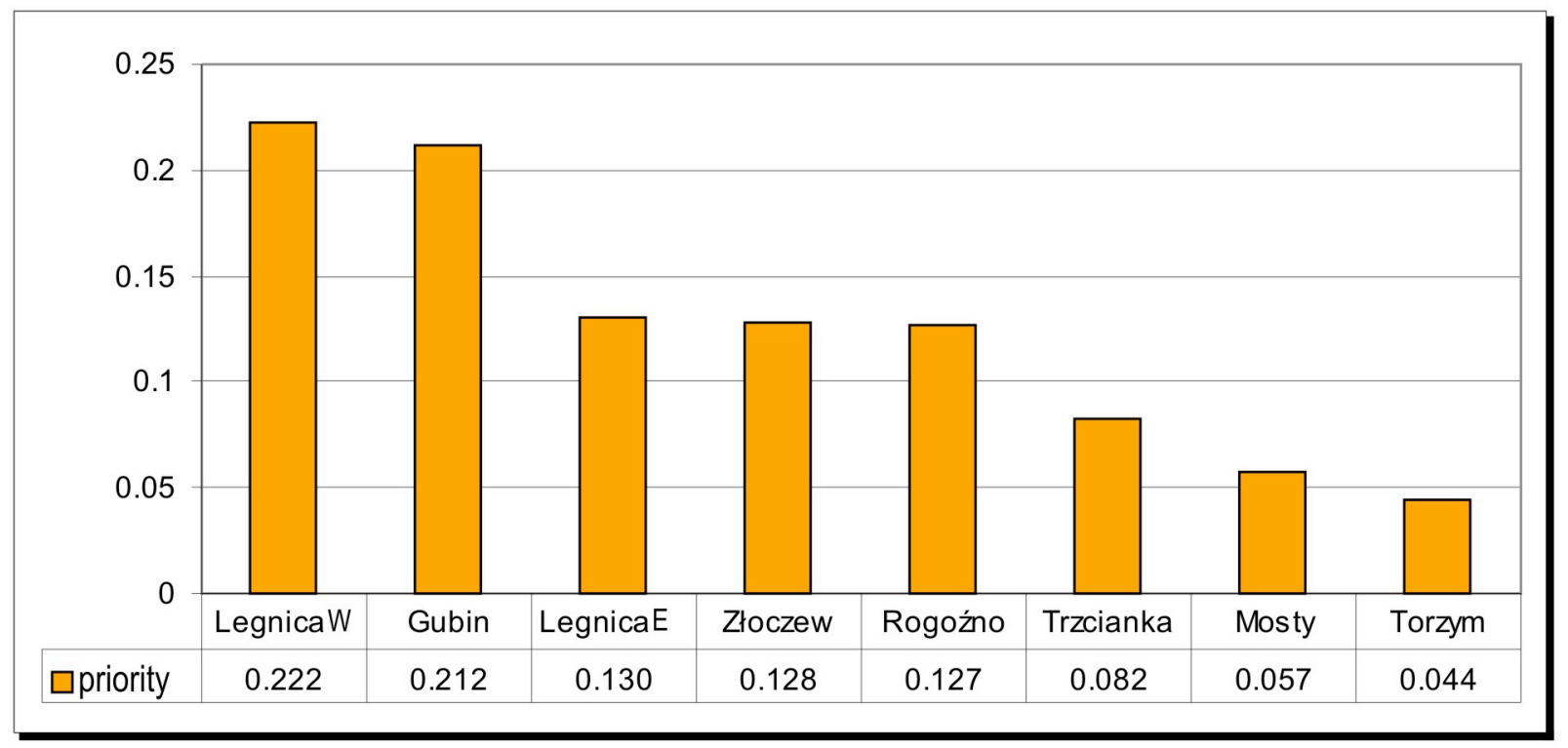

Figure 3. Global vector for the variants - lignite deposits

The presented ranking of lignite deposits established by the AHP method should be treated only as an initial attempt at ordering the selected group of lignite deposits in a hierarchy. The results of the deposits' valorisation are similar to the results from some of the rankings cited in this paper. 
The attempt of applying the AHP method for establishment of a ranking of lignite deposits made in this article show its full usefulness for these aims. Yet, the established ranking needs to be verified and wider research and analysis need to be carried out first in order to obtain more detailed information about lignite deposits and a concept of their development. It needs to be emphasised that verification of the information about deposits and the areas on which they are located is a time-consuming and expensive activity that is nonetheless advisable after the verification of the usefulness of applying the AHP method. Involvement of a bigger group of experts and preparation of information standardized in terms of its form and accuracy would hence be possible.

\section{Ranking of deposits and spatial planning}

As previously mentioned, the goal of the valorisation of lignite deposits and the establishment of their ranking is the selection from among around 150 recognized lignite deposits those which are the most attractive for development and then their protection against investments other than mining. Protection of lignite deposits is important for the energy security of Poland. One of the aims of Poland's policy on energy is to ensure stable fuel and energy supply at a level that ensures the satisfaction of national needs and at prices acceptable by the economy and society with the assumption of the optimal use of national raw energy resources.

Therefore, the most attractive lignite deposits selected by the AHP method should be included in Poland's policy on energy and then their protection should be ensured in spatial planning documents. However, a shortcoming of spatial planning regarding real estates with mineral deposits is the fact that although the legal regulations currently in force point at the necessity of taking into consideration limits of the documented deposits in spatial planning documents, this does not guarantee protection of these real estates (Mining and Geological Law, 1994 and the Act on Spatial Planning and Space Management, 2003). The designation of real estate for mining activity in the local land use plan is only the basis for the procurement of a license for mineral extraction.

Although it is not obligatory to prepare a local land use plan, such a document is necessary for the execution of investment projects. In turn, although it is obligatory to prepare a study for the commune, such a document is not the basis for the commencement of a mining investment. Since extraction of lignite deposits serves public purposes, in a situation when there is a lack of a local land use plan, the Act on spatial planning and land use management gives other possibilities of obtaining a license for the development of deposits.

In the event of execution of investments for public purpose, a decision on location of a public purpose investment' may act as a substitute for a local land use plan. On the basis of the Act on spatial planning and land use management it is possible to create three scenarios aimed at the protection of real estate with mineral deposits and obtaining a licence for their extraction. The choice of the scenario depends on the attractiveness of the mineral deposit and its significance for the economy, as well as social acceptance. The scenarios that may be applied are as follows (Uberman, Ostręga, 2009):

Scenario I - "Establishment of the location of a public purpose investment" can be applied in the case of a public purpose investment e.g. extraction of lignite deposits whereby there is no local land use plan at the same time.

Scenario II - "Introduction of an investment concerning mineral deposit extraction to a local land use plan" can be applied in the case of extraction of all kinds of minerals in a situation when the local land use plan does not include mining investments or there is a lack of such a plan, assuming acceptance of the local government. 
Scenario III - "Introduction of a public purpose investment concerning lignite deposit extraction of nationwide importance to the local land use plan through conception of spatial development of the country and governmental task" can be applied in a situation when mineral extraction serves a public purpose, hence beside mineral extraction by underground and drilling methods, only for one mineral extracted by open cast method - namely lignite.

For Poland, where approx. 30\% of the power industry is based on lignite, not only recognition of the resources but also their valorisation concerning attractiveness for development and establishment of a ranking of lignite deposits is very important. The most attractive deposits should be included in Poland's policy on energy and this should be reflected in the appropriate provisions being made in strategic documents ensuring the protection of deposits.

\section{Conclusion}

As a result of the conducted studies and analyses, the following conclusions can be made:

1. Analysis of the few studies concluded to date concerning mineral deposits' valorisation shows that this is a problem recognized in a small extent and it has only been partly solved. Only four studies in Polish literature directly address the valorisation of mineral deposits. The remaining studies deal with problems of classification of structures (project concepts) related to mining.

2. The main flaw of the studies on the valorisation of mineral deposits is the application of a limited number of factors characterising mineral deposits and significant subjectivity of the evaluations resultant from the application of point methods.

3. Due to the complexity of the problem concerning mineral deposits' valorisation, it was necessary to search for a method that would enable establishment of a ranking taking into account a larger number of factors characterizing mineral deposits (measurable and non-measurable) and which would ensure a higher degree of objectivity in the evaluation.

4. The attempt of applying the analytic hierarchy process to rank lignite deposits confirms its full usefulness for these purposes.

5. It would be advisable to conduct wider studies on lignite deposits' valorisation using the AHP method in order to protect at least part of the most attractive lignite deposits against investments other than those related to mining.

6. The established ranking of lignite deposits should be included in Poland's policy on energy and also in spatial planning documents at each administrative level in the country.

\section{REFERENCES}

Ekspertyza nt. „Kompleksowego wykorzystania i zagospodarowania obszarów wydobycia węgla brunatnego w Polsce”. Kraków, Komitet Gospodarki Surowcami Mineralnymi PAN (1982).

Ekspertyza Polskiej Akademii Nauk - Oddział w Poznaniu pt. „Skutki przyrodnicze, społeczne i gospodarcze eksploatacji poznańskich złóż węgla brunatnego”. Poznań (1980).

Kasiński J.R., Mazurek S., Piwocki M. (2006). Waloryzacja i ranking złóż węgla brunatnego w Polsce. Warszawa, Wyd. PGI Nr CLXXXVII.

Kasztelewicz Z. (2005). Metoda programowania zagospodarowania złóż w wieloodkrywkowej kopalni węgla brunatnego. Kraków, Uczelniane Wydawnictwa Naukowo-Dydaktyczne. Seria Rozprawy, Monografie. 
Nieć M. (2004) - Problemy ochrony złóż kopalin. Warszawa, Wyd. Min. Środ. I KZK. pt. „Problemy gospodarki złożem kopalin. 50 lat działalności Komisji Zasobów Kopalin.

Obwieszczenie Ministra Gospodarki i Pracy z dn. 1 lipca 2005 r. w sprawie polityki energetycznej państwa do 2025 r. (M.P. Nr 42, poz. 562).

Ostręga A. (2004). Sposoby zagospodarowania wyrobisk i terenów po eksploatacji złóż surowców węglanowych na przykładzie Krzemionek Podgórskich w Krakowie. Rozprawa doktorska. Kraków, Biblioteka Główna AGH.

Piwocki M., Kasiński J.R. (1993). Metoda ekonomiczno-sozologicznej waloryzacji złóż węgla brunatnego. Przeglad Geologiczny nr 5.

Piwocki M., Kasiński J.R. (1994). Mapa waloryzacji ekonomiczno-środowiskowej złóż węgla brunatnego w Polsce, Warszawa. Wyd. PGI.

Saaty T.L. (2001). Decision-Making for Leaders. The Analytic Hierarchy Process for Decision in a Complex world. Vol. II, Pittsburgh, RWS Publications.

Sokulska-Pietrzyk E. (2005). Kryteria i kierunki adaptacji terenów do eksploatacji surowców skalnych. Kraków, Wydawnictwo IGSMiE PAN. Seria Studia, Rozprawy, Monografie. Nr 131. 